\title{
Investigations into the teratogenic potentials of lead in pregnant rabbit
}

\author{
A.M. TAIWO ${ }^{1}$, E.A. ALUKO ${ }^{1}$ and O.O. BABALOLA ${ }^{2 *}$ \\ ${ }^{l}$ Department of Environmental Management \& Toxicology, University of Agriculture, Abeokuta, Nigeria. \\ ${ }^{2}$ Department of Biochemistry, Obafemi Awolowo University, Ile-Ife, Nigeria. \\ ${ }^{*}$ Corresponding author, E-mail: doctorbablo@yahoo.com
}

\begin{abstract}
The study was designed to assess the teratogenic potentials of lead on pregnant rabbit. Lead in lead acetate $\left(\mathrm{CH}_{3} \mathrm{COO}\right)_{2} \mathrm{~Pb} .3 \mathrm{H}_{2} \mathrm{O}$ solution prepared at varying concentrations of $0 \mathrm{ppm}, 50 \mathrm{ppm}$ and $100 \mathrm{ppm}$ were orally administered to three pregnant rabbits from day 7 to day 29 of gestation. Each mother rabbit gave birth to 4,5 and 5 offsprings respectively; these were raised for 4 weeks. After weaning the rabbit offsprings, the blood of both mother and baby rabbits were collected through the aid of syringes and transferred to the laboratory for analysis. Total protein, albumin, creatinine, urea in blood plasma were determined by standard spectrophotometric technique and blood lead $(\mathrm{PbB})$ was determined by atomic absorption spectrophotometry. The weights of the offsprings were also taken. The results obtained showed that there is a decrease in total protein and albumin and an increase in creatinine and urea in baby rabbits given a concentration of $50 \mathrm{ppm}$ and $100 \mathrm{ppm}$ respectively when compare to the control $(0 \mathrm{ppm})$. Analysis of variance at $\mathrm{p}<0.05$ revealed a level of significance in all the blood parameters while there were no significant differences in the weights of the offsprings. The histology of liver and kidney of mother rabbits also depicted toxicity of lead in mother rabbits. (C) 2010 International Formulae Group. All rights reserved.
\end{abstract}

Keywords: Lead, pregnancy, teratogenic, histology, blood parameters

\section{INTRODUCTION}

Teratogenicity is the formation of birth defects or abnormality in offsprings via maternal exposure to xenobiotics, chemicals or environmental condition (Kamrin, 1988). Certain chemicals including metal ions and some drugs like thalidomide may influence tissues to different degrees according to the development state, functional condition and activity of fetus during pregnancy (Lenz, 1961). Mulder et al. (2000) observed that even excess vitamin $\mathrm{A}$ and its metabolites (retinoic acid) on the CNS can be teratogenic. It has been documented in literatures that certain drugs also induce hormonal changes in male or female and may impair libido, reproduction cycles, or gem cell production resulting to reproductive failure (Anetor et al., 2002; Lansdown, 1983). High fetal and neonatal mortality, declining birth rates, increase in birth of children with structural and functional defects have also been documented (Widschiff et al., 1987; Babalola et al., 2005; Edwards, 1969; Kamrin, 1988). Between 1958 and1961 about 10,000 children with severe limb defects were born because their mothers during pregnancy had taken thalidomide drugs (Paulus, 1999). Fuetes et al. (1996) had earlier demonstrated that lead is capable of reducing the placental weight significantly. 
Teratogenic effects of lead have also been demonstrated in rodents and human studies (Goyer, 1991). Additionally other metals that are likely to injure human reproduction with population studies include mercury, infact accidental mercury poisoning was reported in Iraq and Japan (Goyer, 1991). It has been found that high levels of paternal lead exposure for years could reduce fertility and increase the risks of spontaneous abortion and reduced fetal growth while chronic maternal lead exposure could lead to increase risks of pregnancy hypertension, spontaneous abortion, reduced offsprings and neurobehavioral development (Bellinger, 2005). Spiro and Stigliani (1996) also documented various lead induced toxic effects to include anemia, reduced brain weight, fetal deaths, increased aggressively, reduced survival, abortions, urinary inconsistence, hypertension, anxiety, poor concentration, forgetfulness, mild reduction in motor and sensory nerve conditions, sperm abnormality, irreversible severe brain damage and restricted growth. The main objective of this current study is to evaluate the possible teratogenic potentials of lead using experimental animals.

\section{MATERIALS AND METHODS}

\section{Animals}

Three virgin female rabbits of New Zealand breed weighing $2.35 \mathrm{~kg} ; 2.15 \mathrm{~kg}$ and $2.05 \mathrm{~kg}$ were used for the study. They were made to acclimatize to laboratory condition for 4 weeks and later mated with male rabbit of same breed for two consecutive days. The second day of mating was designated as day 1 of gestation period. The rabbit received 0 ppm, $50 \mathrm{ppm}$ and $100 \mathrm{ppm}$ of lead orally, between day 7 and 29 of gestation. The rabbits gave birth to their offsprings after day 30 of gestation. The offsprings were allowed to wean after 4 weeks of birth before the collection of blood sample took place. About $5 \mathrm{ml}$ of blood samples were collected from both mother and 4-week-old baby rabbits with the aid of syringes. Some portions of the blood samples were immediately transferred into heparinized bottles to prepare blood plasma.

\section{Biochemical analysis}

Plasma total protein content was determined by biuret reaction method (Cannon et al., 1974). The plasma albumin level was determined by the modified method of Pinnell and Northan (1978). Creatinine and urea determination was carried out using colorimetric methods [Taussky (1956) and Doulumbe and Frauseau (1963) respectively]. The blood lead was determined by atomic absorption spectrophotometric method.

\section{Histology examination}

The histology of the liver and kidney of the mother rabbits were examined through the aid of microphotographs of the staining cut samples. The histology of both liver and kidney samples were done at University College Hospital (UCH) Ibadan, Nigeria.

\section{RESULTS AND DISCUSSION}

The results obtained from this study supported the hypothesis that lead can transverse the placenta barrier from the mother rabbit to the offsprings. Similar theory has been established in both rodents and human (McClan and Becker, 1974; Anetor et al., 2002). The mean blood lead was higher in the test animals than control $(0 \mathrm{ppm})$. The high blood lead content could be responsible for the observed decrease in total protein and albumin and consequent elevation of urea and creatinine (Table 1). Transfer of lead from mother rabbit to the offspring was also evident in Table 2.

Decrease in total protein and albumin could result into decrease enzyme, reduced immunity system and declined buffering capacity of the body (Warner and Lawrence, 1988; Nduka, 1999). Lead absorption into the blood system may suppress the oxygen carrier hemoglobin and disturb fibrinogen. This may lead to hemolytic destruction of hemoglobin leading to decrease in total protein and albumin, which help transport substances in the blood. Total protein and in particular 
albumin are essential transport medium of variety of substances (Max et al., 1980). The values obtained from both creatinine and urea were higher in test animals than the control. While creatinine is formed in the muscle, urea is formed in the liver of the animal (Nduka 1999; O’Donnell, 2004). High urea and creatinine in blood of the test animals is probably an indication of renal failure. High lead content in the blood of the test animals might have resulted into renal dysfunction of the animals thereby leading to high accumulation of urea and creatinine, which could also lead to impairment of electrolytes and Hydrogen homeostasis (Warner and Lawrence, 1988).
Statistically, there were significant differences in total protein, albumin, urea, creatinine and blood lead while only the weight showed no level of significance at $p<0.05$ (Table 3). Lead transfer into the offspring appears not to affect the weight of the animals. Duncan Multiple Range Test also revealed that there was a significant difference between the control $(0 \mathrm{ppm})$ and tests animals subjected to $100 \mathrm{ppm} \mathrm{Pb}$ while there was no significant difference between control and test animals subjected to $50 \mathrm{ppm} \mathrm{Pb}$ (Table 2). Pearson correlation revealed that there is a positive significant correlation between total protein and albumin (0.593) and significant negative correlation with blood lead $(-0.655$ at $\mathrm{p}<0.05)$ (Table 4).

Table 1: Toxicological examinations of biochemical parameters in the serum of mother rabbits.

\begin{tabular}{lcccccc}
\hline Parameters & $\begin{array}{l}\text { Total } \\
\text { protein } \\
(\mathbf{g} / \mathbf{d l})\end{array}$ & $\begin{array}{l}\text { Albumin } \\
(\mathbf{g} / \mathbf{d l})\end{array}$ & $\begin{array}{l}\text { Urea } \\
(\mathbf{m m o l} / \mathbf{d l})\end{array}$ & $\begin{array}{l}\text { Creatinine } \\
(\mathbf{m g} / \mathbf{l})\end{array}$ & $\begin{array}{l}\text { Blood } \\
\text { lead } \\
(\mathbf{m g} / \mathbf{l})\end{array}$ & $\begin{array}{l}\text { Weight } \\
(\mathbf{k g})\end{array}$ \\
\hline $0 \mathrm{ppm}(\mathrm{Control})$ & 9.78 & 6.60 & 0.90 & 0.63 & 0.18 & 2.35 \\
\hline $50 \mathrm{ppm}$ & 9.31 & 6.01 & 3.0 & 0.65 & 0.26 & 2.15 \\
\hline $100 \mathrm{ppm}$ & 8.46 & 5.28 & 4.8 & 0.68 & 0.29 & 2.05 \\
\hline
\end{tabular}

Table 2: Toxicological examinations of biochemical parameters in the serum of baby rabbits.

\begin{tabular}{lcccccc}
\hline Parameters & $\begin{array}{c}\text { Total } \\
\text { Protein } \\
(\mathbf{g} / \mathbf{d l})\end{array}$ & $\begin{array}{c}\text { Albumin } \\
(\mathbf{g} / \mathbf{d l})\end{array}$ & $\begin{array}{c}\text { Urea } \\
(\mathbf{m m o l} / \mathbf{d l})\end{array}$ & $\begin{array}{c}\text { Creatinine } \\
(\mathbf{m g} / \mathbf{l})\end{array}$ & $\begin{array}{c}\text { Blood } \\
\text { lead } \\
(\mathbf{m g} / \mathbf{l})\end{array}$ & $\begin{array}{c}\text { Weight } \\
(\mathbf{k g})\end{array}$ \\
\hline $0 \mathrm{ppm}(\mathrm{Control})$ & $6.47 \pm 056^{\mathrm{b}}$ & $3.95 \pm 1.02^{\mathrm{b}}$ & $2.53 \pm 0.46^{\mathrm{a}}$ & $0.55 \pm 0.13^{\mathrm{a}}$ & $0.11 \pm 0.03^{\mathrm{a}}$ & $0.15 \pm 0.00^{\mathrm{a}}$ \\
\hline $50 \mathrm{ppm}$ & $5.60 \pm 0.85^{\mathrm{b}}$ & $3.17 \pm 0.75^{\mathrm{ab}}$ & $3.25 \pm 1.00^{\mathrm{ab}}$ & $0.61 \pm 0.06^{\mathrm{ab}}$ & $0.16 \pm 0.05^{\mathrm{ab}}$ & $0.16 \pm 0.03^{\mathrm{a}}$ \\
\hline $100 \mathrm{ppm}$ & $4.07 \pm 0.83^{\mathrm{a}}$ & $2.40 \pm 0.15^{\mathrm{a}}$ & $4.18 \pm 0.99^{\mathrm{b}}$ & $0.79 \pm 0.12^{\mathrm{b}}$ & $0.22 \pm 0.03^{\mathrm{b}}$ & $0.17 \pm 0.03^{\mathrm{a}}$ \\
\hline
\end{tabular}

Table 3: ANOVA of biochemical properties of blood serum of baby rabbits.

\begin{tabular}{lcc}
\hline Parameters & F & Significance \\
\hline Total Protein & 8.287 & .008 \\
Albumin & 5.001 & .031 \\
Urea & 5.288 & .027 \\
Creatinine & 4.511 & .040 \\
Blood Lead & 7.461 & .010 \\
Weight & 1.554 & .258 \\
\hline
\end{tabular}


Table 4: Pearson correlation coefficient of biochemical properties of blood serum of baby rabbits.

\begin{tabular}{lllllll}
\hline & $\begin{array}{l}\text { Total } \\
\text { protein } \\
(\mathrm{g} / \mathrm{dl})\end{array}$ & $\begin{array}{l}\text { Albumin } \\
(\mathrm{g} / \mathrm{dl})\end{array}$ & $\begin{array}{l}\text { Urea } \\
(\mathrm{mmol} / \mathrm{dl})\end{array}$ & $\begin{array}{l}\text { Creatinine } \\
(\mathrm{mg} / \mathrm{l})\end{array}$ & $\begin{array}{l}\text { Blood lead } \\
(\mathrm{mg} / \mathrm{l})\end{array}$ & $\begin{array}{l}\text { Weight } \\
(\mathrm{kg})\end{array}$ \\
\hline $\begin{array}{l}\text { Total Protein } \\
(\mathrm{g} / \mathrm{dl})\end{array}$ & 1 & & & & & \\
\hline Albumin $(\mathrm{g} / \mathrm{dl})$ & $.593^{*}$ & 1 & & & & \\
\hline Urea $(\mathrm{mmol} / \mathrm{dl})$ & -.524 & -.398 & 1 & & & \\
\hline Creatinine $(\mathrm{mg} / \mathrm{l})$ & -.472 & -.591 & .376 & 1 & & \\
\hline Blood lead $(\mathrm{mg} / \mathrm{l})$ & $-.655^{*}$ & -.408 & -.422 & .543 & 1 & \\
\hline Weight $(\mathrm{kg})$ & -.405 & -.511 & .277 & .173 & .398 & 1 \\
\hline
\end{tabular}

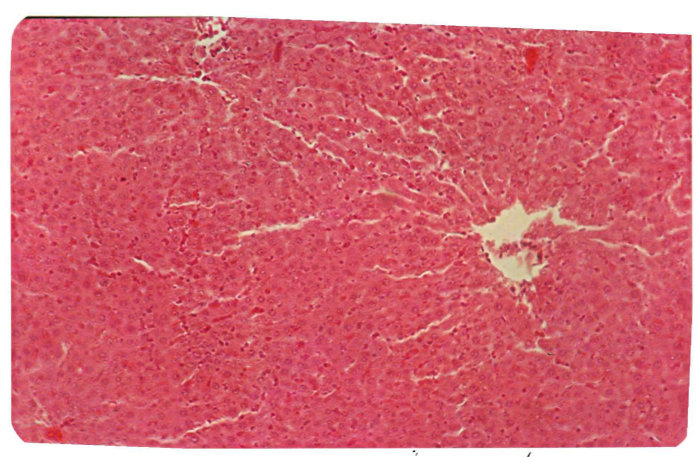

Plate 1: Histological photograph of liver (control, 0 ppm).

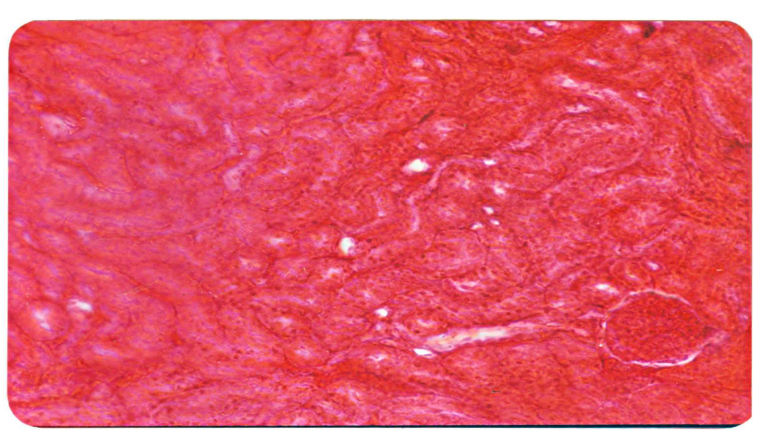

Plate 2: Histological photograph of liver (50 ppm).

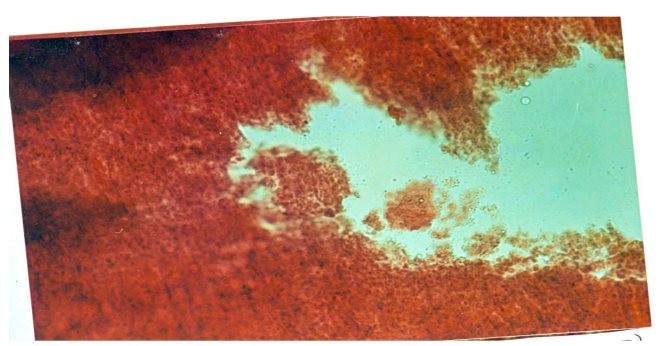

Plate 3: Histological photograph of liver (100 ppm). 


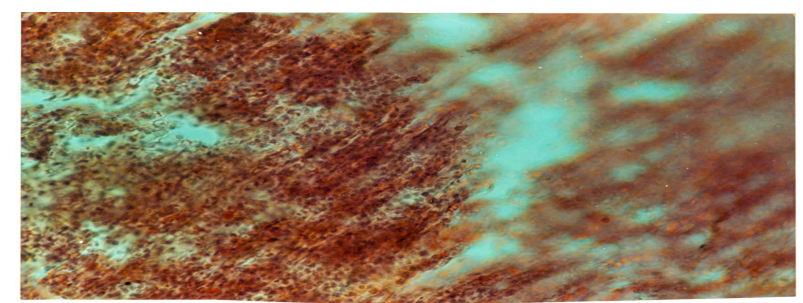

Plate 4: Histological photograph of kidney (control, 0 ppm).

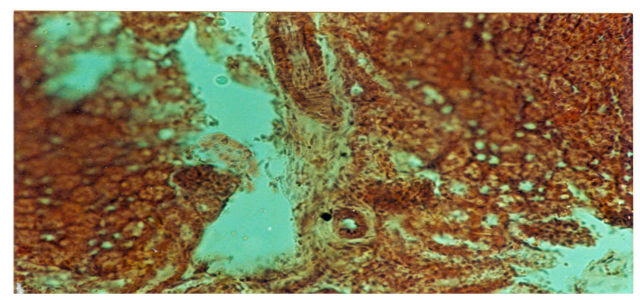

Plate 5: Histological photograph of kidney (50 ppm).

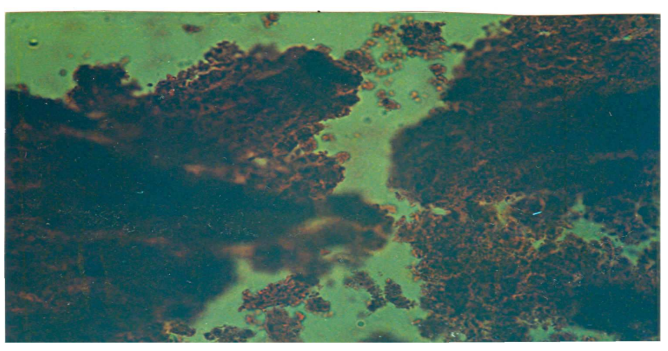

Plate 6: Histological photograph of kidney (100 ppm).

The histological examination of liver revealed some morphological changes as there was basophilic stripling of erythrocytes (plate 1-3). This was more pronounced in test animals given doses of $100 \mathrm{ppm}$ and $50 \mathrm{ppm}$ respectively. In the case of kidney, the histology revealed a wanton damage of glomerulus's cells (plate $4-6$ ).

The results obtained from various blood parameters showed that there was a transfer of lead from mother rabbit to offspring. The toxicity of lead was also established from the histological examination of kidney and liver. Conclusively from the result lead is probably teratogenic.

\section{REFERENCES}

Anetor JI, Babalola OO, Adeniyi FA, Akingbola TS. 2002. Observations on the heamopoietic system in tropical lead poisoning. Nigerian Journal of Physiological Sciences, 17(1-2): 9-15.

Babalola OO, Ojo LO, Aderemi MO. 2005. Lead levels in some biological samples of aeromechanics in Abeokuta, Nigeria. Indian J. Biochem. Biophys., 42: 401-403.

Bellinger DC. 2005. Teratogen update: lead and pregnancy. Wiley Interscience, 73(6): 409-420.

Cannon DC, Olitzky GA, Inkpen JA. 1974. Protein in Clinical Chemistry and Techniques ( $2^{\text {nd }}$ edn). Henry RJ, Cannon D.C and Winkleman W. (eds). Harpe and Row: New York; 407-421.

Coulombe JS, Frauseau LA. 1963. A simple colorimetric method for the determination of of urea in the presence of diacety 
monoxine and thiosemicarbazide. Clin. Chem., 9: 102-104.

David, C. Bellinger 2005. Teratogen update: lead and pregnancy. Wiley Interscience, 73(6): 409-420

Fuetes M, Torregrossa A, Mora R, Gotzens V, Domingo JL. 1996. Placental effects of lead in mice. J. Placenta., 17(5-6): 371376.

Goyer R. 1991. Toxic effects of metals. In Casarett and Doull's Toxicology (4th edn), Amdur MO, Doull JD, Klaassen CD (eds). Pergamon Press: New York; 623680.

Kamrin MA. 1988. Toxicology: A primer on toxicology principle and application. Lewis Publishers, Inc: Chelsea, Michigan; 38-39.

Lansdown ABG. 1983. Teratogenicity and reduced fertility from factors present in food. In Toxic Factors in Food. Conning DM, ABG (eds). Lansdown: CroomHelm, London; 73-121.

McClain RM, Becker BA. 1974. Teratogenicity, fetal toxicity, and placental transfer of lead nitrate in rats. Toxicol. Appl. Pharmacol., 31: 72.

Max ER, James AH, Anatoly HB. 1980. General Principle in Pediachtric Pharmacology and Toxicology. Hemisphere publishing: Washington DC; $1-15$.

Mulder GB, Manley N, Grant J, Schmidt K, Zeng W, Eckhoff C, Maggio-Price L. 2000. Effects of excess vitamin A on development of cranial neural crestderived structures: A neonatal and embryological study. NLM: Teratology, 62: 214-26.
Nduka N. 1999. Clinical Biochemistry for Students of Pathology ( $1^{\text {st }}$ edn). Longman Nigeria Plc: Ikeja, Lagos; 125-126.

O’Donnell J. 2004. Polar Hysteria: An expression of hypervitaminosis A. Am. $J$. Ther., 11: 507- 516.

Parson PJ. 1991. Blood lead determination by electrothermal atomization atomic absorption spectrometry with PerkinElmer 4100 ZL AAS. Wadsworth Center Lead Poisoning Laboratory, State Department of Health, Albany NY, p. 1.

Paulus WE. 1999. Pharmacotheraphy in pregnancy. Ther Umsch., 56(10): 602-7.

Pinnel AE, Nothan BE. 1978. New automated bye-binding method for serum dtermination with bromocresol purple. Clin. Chem., 24: 80.

Spiro TG, Stigliani WM. 1996. Chemistry of the Environment. Prentice Hall: Upper Saddle River, NJ; 333 pp.

Uriagu JO. 1988. The Biochemistry of Lead in the Environment. Part A, Ecological Cycles. Elsivier: North Holland, Amsterdam; 92.

Taussky HH. 1956. A modified alkaline picrate method of determination of creatinine in serum. Clin. Chima. Acta., 1: 200-202.

Warner GL, Lawrence DA. 1988. The effect of metals on IL-2 related lymphocyte proliferation. Int. J. Immunopharmacol., 10(5): 629-37. 